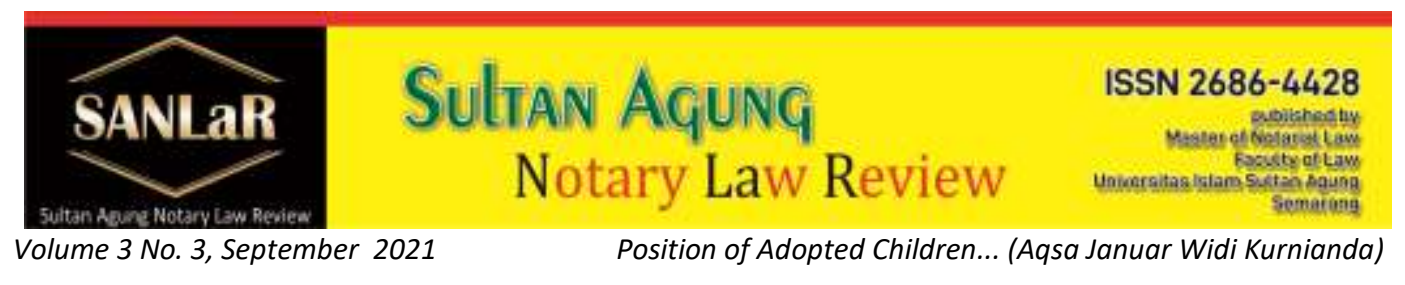

\title{
Legal Cancellation of Property Rights Certificate to Land which is Enough with Insurance Rights
}

\author{
Aqsa Januar Widi Kurnianda*) \\ ${ }^{*}$ Faculty of Law, Universitas Islam Sultan Agung (UNISSULA) Semarang, E-mail: \\ aqsajwk2021@gmail.com
}

Abstract. If observed, the provisions of Article 32 paragraph (1) of the PP on Land Registration have weaknesses, where the state does not guarantee the truth of the physical data and juridical data presented and there is no guarantee for the certificate owner because at any time they will get a lawsuit from other parties who feel aggrieved over issuance of certificate. And if it turns out that in the future the land rights are disputed and the mortgage giver is declared not as the person / party entitled to the land, which will thus have implications for the mortgage that burdens the land rights. This study aims to find out the legal consequences of canceling a certificate of ownership of land that is being encumbered by Mortgage at the Land Office of Palembang City and to find out the legal protection for separate creditors as holders of Mortgage on the canceled land title certificate. The approach method used in writing this law is sociological juridical which means carried out with observation steps carried out in accordance with the formulation of the problem, collecting data from literature or doctrinal research from secondary materials and interviews and to find out the problems being researched which in this case relates to the object. study. The research problem is analyzed with the theory of authority, the theory of legal certainty, and the theory of legal protection. The results of the study indicate that the legal consequences of canceling the certificate of ownership of land that are being encumbered with Mortgage Rights, namely the change in the position of the creditor, which was originally located as a preferred creditor which has material rights, then is located as a concurrent creditor who has individual rights. Legal protection for creditors for the abolition of the object of mortgage can be obtained with preventive legal protection and repressive legal protection. Preventive legal protection is legal protection that is preventive in nature, that is, it can be through an agreement by including a clause regarding the replacement of the dependent object with other objects owned by the debtor in the event of the elimination of the right to the dependent object that is burdened with the mortgage.

Keywords: Mortgage; Guarantee; Object; Cancel. 


\section{Introduction}

One of the goals of the Republic of Indonesia is stated in the preamble of the 1945 Constitution of the Republic of Indonesia (the 1945 Constitution of the Republic of Indonesia). The fourth paragraph is to promote the general welfare realized by a state government. The republic of Indonesia whose structure of people's lives, including the economy, is mainly still an agrarian pattern. Earth, water, and space, as gifts from God Almighty have a very important function to build a just and prosperous society as aspired to, then in article 33 paragraph 3 of the 1945 Constitution of the Republic of Indonesia it is stated that the earth, water and natural resources contained in it is controlled by the State which is used as much as possible for the benefit of the community.

In its development, land is a means and a very important need for human life. Land certificates are very important for the owner to prove ownership rights to land. Land and certificates are two things that cannot be separated and complement each other. Certificates are valid and strong evidence that a person has regarding land rights. The certificate is a marker or proof that the person whose name is listed in the certificate is the rightful owner because land is an immovable object. This is an acknowledgment and affirmation from the state of individual or joint ownership of land or a legal entity whose name is written in the certificate and at the same time explains the location, picture of the situation, the size and boundaries of the plot of land. In order for this to be enjoyed by land rights holders, registration of the land object is required.

In national land law, it is known that individual rights to land can be in the form of land rights and land security rights. The definition of Collateral over land or mortgage is according to Article 1 point 1 of Act No. 4 of 1996 concerning Mortgage on Land and Objects Relating to Land (UUHT) are:

"The security rights imposed on land rights as referred to in Act No. 5 of 1960 concerning Basic Regulations on Agrarian Principles and whether or not including other objects that are an integral part of the land for the settlement of certain debts, which provide position that is prioritized for certain creditors over other creditors. ${ }^{1 "}$

Collaterals regulated in mortgage rights are only imposed on land with certificates of ownership rights, building use rights and cultivation rights ${ }^{2}$. A plot of land that is used as a guarantee for repayment of a debt to a bank, it is not enough just to make a deed of granting mortgage rights, but the deed must be registered at the land office. After the completion of the mortgage registration

\footnotetext{
${ }^{1}$ Article 1 point 1, Act No. 4 of 1996 concerning Mortgage on Land and Objects related to Land.

${ }^{2}$ Article 4 point 1 , Act No. 4 of 1996 concerning Mortgage Rights
} 
process, the land office issues a mortgage certificate which is proof of the existence of a mortgage right. Mortgage certificates and certificates are usually held by the creditor or the bank, until the credit period ends or the land owner pays off the debt to the bank.

Based on Article 32 paragraph (1) of the PP on Land Registration, the land registration publication system adopted is a negative publication system, i.e. the certificate is only a certificate of proof of strong rights and is not a letter of proof of absolute rights. This means that the physical data and juridical data contained in the certificate have legal force and must be accepted by the judge as true information as long as and as long as there is no other evidence that proves otherwise. Thus, the competent court decides which evidence is correct and if it is proven that the certificate is not correct, changes and corrections will be made accordingly.

If observed, the provisions of Article 32 paragraph (1) of the PP on Land Registration have weaknesses, namely the state does not guarantee the truth of the physical data and juridical data presented and there is no guarantee for the certificate owner because at any time they will get a lawsuit from other parties who feel aggrieved over issuance of certificate. However, from the beginning it seemed that the founders had realized it, and finally it was equipped with Article 32 paragraph (2) which affirms that: In the case of a parcel of land, a certificate has been issued legally in the name of the person or legal entity that acquired the land in good faith and in real terms.

Departing from the description above, if it turns out that in the future the land rights are disputed and the mortgage provider is declared not as the person/party entitled to the land, which will thus have implications for the mortgage that burdens the land rights. This condition occurred in the High Court Decision No.94/Pdt/2011/PN.PLG, in which the Plaintiff is the holder of land rights registered as State land controlled by the Indonesian Army, in this case Kodam II/Swj, which is used as the residence of the Dandim Service 0418. / Palembang, that the disputed land and building in 1959 was occupied by Lt. Col. Alwi Sutan Maradjo (Defendant III) as an official of the Dandim based on a Permanent Permit (SIT) for the Official House, Then in 1964 the land and building were occupied by Major Oesman (Parent of Defendants II) as official residence with the position of Dandim 0418, then in 1967 a land sale and purchase transaction occurred between Defendant III as the seller and Major Oesaman as the buyer, both of which realized that the land and buildings belonged to the TNI AD Sriwijaya Kodam which was used as the official residence of Dandim officials. Whereas the Plaintiff had previously sent a notification to Defendant IV (BPN Palembang City) that the land belonged to the TNI AD Kodam II Sriwijaya and had never been transferred to another party, and in 1976 the Pangdam IV Sriwijaya 
(Kodam II/Swj) through his letter ordered the evacuation of the house. This service $^{3}$ was occupied by Major (Ret.) Oesman and his children (Defendants II, but Defendant II did not heed but then Defendant II and Defendant I made a land sale and purchase transaction with Certificate Number Number 60 dated June 6, 2006 on behalf of Defendant I which according to the Plaintiff the Acknowledgment Letter and the Deed of Transfer made were legally flawed and must be cancelled. In this case, the judge decided that the certificate was canceled and legally belonged to the Plaintiff.

\section{Research Methods}

The approach method used in this research is sociological juridical and empirical juridical. Sociological juridical, namely research carried out with observation steps carried out in accordance with the formulation of the problem, collecting data from literature or doctrinal research from secondary materials and interviews and to find out the problems being studied which in this case relate toLegal Consequences of Cancellation of Ownership Certificates on Land Encumbered with Mortgage Rights (Case Study at the Land Office of Palembang City). The juridical empirical is an approach that examines secondary data first and then continues by conducting primary data research in the field. ${ }^{4}$

Types and Sources of Data in the form of: 1. Primary data is obtained from a binding source in the cancellation of the certificate of ownership of land that is being encumbered with mortgage rights. In this study using the types and sources of primary data, primary data itself is data obtained by the author directly from the community. This data is taken from individual sources or individuals by conducting an interview with the informant. The interview itself is a way to obtain information needed in a research that is being carried out. Interviews were used to complete data from researchers that were not obtained in the literature study. 2. Secondary Data i.e. is data obtained by researchers from the literature which is the result of research. Which is already available in the form of books which are usually provided in the library. ${ }^{5}$ Secondary data sources used in this study include official documents, books, research results in the form of reports. Secondary data in this study are in the form of legal materials as follows:

Legal materials consist of: 1 . Primary legal materials, namely: the Civil Code, the Civil Procedure Code, the Act No. 5 of 1960 concerning Basic Regulations on

\footnotetext{
${ }^{3}$ Deen, Thaufiq., Ong Argo Victoria \& Sumain. (2018). Public Notary Services In Malaysia. JURNAL AKTA: Vol. 5, No. 4, 1017-1026. Retrieved from http://jurnal.unissula.ac.id/index.php/akta/article/view/4135

${ }^{4}$ https://www.google.com/search?client=firefox-b-d\&q=yuridis+empiris+adalah June 16, $2021 \mathrm{At}$ $02: 43$

${ }^{5}$ Hilman Hadikusuma, 1995, Metode Pembuatan Kertas Kerja atau Skripsi IImu Hukum, Mandar Maju, Bandung, p. 65
} 
Agrarian Principles, the Act No. 4 of 1996 concerning Mortgage on Land and Objects Related to Land. Act No. 10 of 1998 concerning Banking, Act No. 2 of 2014 concerning Amendments to Act No. 30 of 2004 concerning the Position of Notary (State Gazette of the Republic of Indonesia of 2014 Number 3), Government Regulation Number 24 of 1997 concerning Land Registration. 2. Secondary Legal Material is data obtained through intermediaries in the form of data and information contained in literature books, results of previous research, journals and so on which is carried out using library research techniques as a reference to obtain the data and information needed. The secondary data used are as follows: Literature Books, Legal Journals and Legal Magazines, Papers, results of seminars, magazines and newspapers, Thesis, scientific articles and accompanied, Opinions of legal practitioners, Research Results. 3. Tertiary data sources legal data that provide explanations of primary legal materials and secondary legal materials, such as examples of legal dictionaries, encyclopedias related to the research carried out.

The collection method is carried out by: 1 . Literature study, which is an indirect data collection technique that is carried out and shown to the research subject, in terms of data obtained from literature, scientific journals, draft laws, research results, scientific articles and regulations legislation related to issues raised by researchers. 2. Field Research or also called (field research) is research conducted by collecting data and information obtained directly from respondents. There are several ways of collecting data, namely: ${ }^{6} a$. The observation method is a technique that is carried out by conducting careful observations and recording systematically; $b$. The interview method is a direct and free guided face-to-face role, when an interviewer asks questions designed to obtain answers that are relevant to the research problem to a respondent on the field data (primary) collected. with the author held a direct question and answer with the Head of the Palembang City Land Office. ${ }^{8}$

The data obtained will be analyzed qualitatively, starting with an inventory of laws and regulations, doctrines, jurisprudence which will then be discussed with the data that has been obtained from the object under study as a unified whole, so that in the final stage a discussion using theory can be drawn. Legal theory and continued with conclusions related to the problems in the research. This method focuses its attention on the general principles that underlie the manifestation of the units of symptoms that exist in human life, or the patterns

\footnotetext{
${ }^{6}$ Rahmatwinarwan92.blogspot.com/2018/11/pengertian-pemelitian-lapangan.html?m=1 accessed on November 20, 23:58 WIB.

${ }^{7}$ Suharismi Arikunto, Dasar-Dasar Evaluasi Pendidikan, Bumi Aksara, Jakarta, 2013, p. 45

${ }^{8}$ Amiruddin \& Zainal Asikin, 2014, Pengantar metode Penilitian Hukum, Raja Grafindo Persada, Jakarta, p.68
} 
that are analyzed by socio-cultural phenomena, using the culture of the community concerned, to obtain an overview of the patterns that occur.

\section{Results and Discussion}

\subsection{Legal Consequences of Cancellation of Ownership Certificates on Land that are Encumbered with Mortgage Rights at the Palembang City Land Office}

Land rights contain the authority, as well as the obligation for the holder of the right to use, in the sense of controlling, using and taking advantage of a certain plot of land owned. Its use contains an obligation to maintain the preservation of its capabilities and prevent its damage, based on the purpose of granting and the contents of the rights as well as the land designation stipulated in the spatial plan of the area concerned.

Therefore, the holder of land rights is not justified to act arbitrarily on his land, because in addition to the authority he has, the owner of land rights also has certain obligations and must pay attention to the prohibitions that apply to him. The social function of each land right can also always be a guideline for land rights holders. The main source in the development of national land law is customary law.

In the case of a right to a plot of land, a certificate is issued legally in the name of a person or legal entity, then the person who acquires the land in good faith and actually controls it, the other party who feels he has the right to the land can demand the implementation of the right since the issuance of the certificate by submitting a written objection to the certificate holder and/or the Head of the relevant Regency/City Land Office or does not file a lawsuit to the Court regarding the control of the land or the issuance of the certificate. ${ }^{9}$

In this case the certificate as proof of rights, when associated with the publication system in Indonesia, adopts a negative publication system that leads to positive publication, where the certificate holder is considered the owner of land rights. Regarding the legal force of the certificate as proof of rights, the provisions of Article 32 PP of Land Registration state that the certificate is a certificate of proof of rights that applies as a strong proof of physical data and juridical data contained therein, as long as the physical data and juridical data are in accordance with the data contained in the letter of measurement and the book of land rights concerned.

\footnotetext{
${ }^{9}$ Results of an interview with Mr. Norman Subowo, Head of the Land Office of Palembang City on Monday, July 8, 2021. At 10.00 WIB
} 
Departing from the description, it can be concluded that the certificate is not a proof of absolute rights. This means that the physical data and juridical data listed in the certificate have legal force and must be accepted by the judge as true information as long as and as long as there is no other evidence that proves otherwise. Thus, it is the court that has the authority to decide which evidence is correct and if it is proven that the certificate is not correct, changes and corrections are made accordingly.

With regard to mortgage rights, if there is a claim from a third party to cancel the certificate of land rights that is being used as an object of collateral by the debtor, and then the court decides that the third party who claims to be the legal owner of the certificate of land rights will result in the right to land rights. the debtor against the collateral object becomes nullified, where the abolition of the debtor's right to the collateral object will result in the annulment of the current mortgage right. This is an example of a case regarding the mortgagee who was declared not the person/party entitled to the land in the High Court Decision No.94/Pdt/2011/PN.PLG.

In the case mentioned above, the Head of the Palembang City Land Office explained that in the Head of Land Regulation No. 4 of 2006 the National Land Agency has one of the duties and functions of handling conflicts, disputes and land cases, which means that the National Land Agency can facilitate meetings between debtors and creditors to resolve disputes over the cancellation of land rights certificates that are used as collateral for mortgages by debtors.

As for the absence of an agreement between the Debtor and the Creditor, the prevailing regulations in Indonesia in general have provided security for creditors in channeling credit to debtors, namely by providing general guarantees according to Articles 1131 and 1132 of Burgerlijk Wetboek (hereinafter referred to as BW), which stipulates that all assets the assets (materials) of the debtor, both movable and immovable, which already exist or will exist, serve as collateral for the entire agreement with the creditor. In the event of a default, all of the debtor's assets are sold at auction and divided according to the size of the receivables of each creditor. The matters described in Article $1131 \mathrm{BW}$ can be concluded that: 1) A creditor can take repayment of any part of the debtor's assets; 2) Every part of the debtor's assets may be sold in order to settle the creditor's bill; 3 ) The creditor's claim rights are only guaranteed by the debtor's property, not by the "debtor person". ${ }^{10}$

The division and grouping of creditors in general civil law has been regulated in the BW which divides creditors into types, namely preferred creditors and concurrent creditors. Preferred creditors are creditors who have the right to take

${ }^{10}$ J.Satrio, Op.cit, p. 34-35 
payment in advance of other creditors and the preferred creditor has priority or privileges over the claims of other creditors. ${ }^{11}$ Meanwhile, concurrent creditors are competing creditors, which means that concurrent creditors do not have special privileges so that they are equal to each other. ${ }^{12}$ These creditors compete with one another to obtain payment from the auction results, so that their position is not prioritized in repayment. ${ }^{13}$ Concurrent creditors are creditors who are not privileged and or are not creditors who were previously agreed upon, so that receivables from concurrent creditors are receivables that are included in the bankruptcy account if the debtor is declared bankrupt by the creditors. And the settlement must also wait for the results of the remaining settlement or auction of the bankruptcy estate and the remainder of the settlement must be distributed after being deducted by the obligation to pay receivables to creditors holding guarantee rights and creditors with special rights proportionally according to the ratio of the amount of the receivables of each of the concurrent creditors (pari passu pro rata parte). ${ }^{14}$

The abolition of the encumbrance of land rights even though the Mortgage Certificate is issued by BPN as an agency or TUN official which is classified as a KTUN, if the land rights certificate is canceled by the decision of the TUN Court, the Mortgage Certificate does not need to be requested for cancellation, but will be canceled automatically. This means that with the cancellation of the certificate of land rights, the certificate of Mortgage will be canceled automatically, in other words, it is not necessary to apply to the TUN Court, but to cancel automatically or it is enough to apply for cancellation to the BPN. And if the certificate is canceled, then according to Article $18 \mathrm{UUHT}$, it will be followed by the abolition of the Mortgage Right. ${ }^{15}$

So according to the author, it is studied with the theory of legal certainty that even though a certificate of land rights has been born and has strong evidentiary power, it does not mean that it will be free from other people's lawsuits who object to the issuance of the certificate of land rights. However, administrative defects can also occur in the issuance, therefore the juridical consequence is the cancellation of the certificate of land rights.

\footnotetext{
${ }^{11}$ Hatta Isnaini Wahyu Utomo, "Hukum Jaminan", Bahan Ajar, Surabaya: Fakultas Hukum Universitas Yos Sudarso, 2017, p. 6

${ }^{12}$ Trisadini Prasastinah Usanti, \& Leonora Bakarbessy, Buku Referensi Hukum Perbankan Hukum Jaminan, Revka Petra Media, 2016, p. 26

${ }^{13}$ Man S. Sastrawidjaja, Hukum Kepailitan \& Penundaan Kewajiban Pembayaran Utang, Bandung: Alumni, 2014, p. 127

${ }^{14}$ Sutan Remy Sjahdeini, Hukum Kepailitian, Jakarta: Grafiti, 2010, p. 6-7

${ }^{15}$ Results of an interview with Mr. Norman Subowo, Head of the Land Office of Palembang City on Monday, July 8, 2021. At 10.00 WIB
} 
And if the mortgage is canceled, there will be legal consequences for the position of the creditor as the holder of the mortgage, namely the first status as a preferred creditor as the holder of material guarantees (because APHT, as a material guarantee agreement, has the principle of ownership and ownership (de preference, professionalism and publicity), and then cancels the mortgage, the status of a creditor changes to a concurrent creditor who at the same time has individual rights that act as general guarantees or rights arising from law caused by the law regulated in Article 1131 of the Civil Code ${ }^{16}$.

So it can be concluded in a general guarantee, all creditors have the same position against other creditors, no creditor is prioritized or privileged over other creditors. The repayment of the debt is divided equally based on the size of the amount of each creditor's claim compared to the total debt of the debtor.

\subsection{Legal Protection for Separate Creditors as Mortgage Holders of Canceled Land Title Certificates}

Mortgage rights are the only institutions for guaranteeing land rights for the settlement of certain debts having one of the principles, namely, among others, giving a preferred position to the creditor. ${ }^{17}$ This means that the creditor holding the Mortgage has the right to take precedence in obtaining repayment of his receivables from other creditors in terms of the proceeds from the sale of the object that is burdened with the Mortgage.

In this case, the nature of the guarantee of Mortgage is that it is an accessory to the agreement that gives rise to a legal relationship of debt and credit (credit agreement). Therefore, the abolition of the Mortgage Rights depends on the main agreement, namely the debt that is guaranteed to be paid off. However, seeing from the strong position of Mortgage in the law that provides executorial rights and gives privileges or prior rights in repayment for creditors against other creditors by directly selling by public auction if the debtor defaults. So according to the author, the abolition of the mortgage due to the problems in this case has an impact on the loss of executorial rights and privileges to creditors in terms of paying off debts is a loss and a legal problem.

Legal protection for creditors is all efforts that guarantee legal certainty to provide protection to creditors' rights in providing credit so that justice can be achieved both in legal regulations and in agreements between creditors and

\footnotetext{
${ }^{16}$ A Chuasanga, Ong Argo Victoria. (2019). Legal Principles Under Criminal Law in Indonesia \& Thailand, Jurnal Daulat Hukum, Vol 2, $\quad$ No $1 \quad$ (2019) http://jurnal.unissula.ac.id/index.php/RH/article/view/4218

${ }^{17}$ Adrian Sutedi. 2010, Hukum Hak Tanggungan, Sinar Grafika, Jakarta, p. 56.
} 
debtors. ${ }^{18}$ Legal protection here aims to minimize risks and even eliminate risks that may arise or have arisen/occurred.

In this case also the National Defense Agency as the agency that issues land rights, namely certificates of rights that to ensure legal certainty for the products made, the National Land Agency carries out very strict stages by checking the entire document on the certificate as well as the requirements in submitting changes to rights on the certificate and if any discrepancies are found, it will not proceed to the change of rights to the land certificate. ${ }^{19}$

According to the author, it is studied with the theory of authority that BPN can be classified as a TUN official, which is authorized to carry out government duties by registering land and issuing land rights certificates. With this, it can be seen that the Government grants authority to BPN, in relation to this authority.

Minister of Finance Decree No. 106/PMK.06/2013 which stipulates that the execution of the auction must be terminated if there is a third party claim other than the debtor/executed against the ownership of the object of collateral. Regulations regarding the settlement of unsecured creditor debt settlement problems. The regulation actually has the effect of hampering the process of repaying receivables in the Bank's business activities as creditors which results in the health of the Bank and public funds.

In the Supreme Court Decision Number 3201K/PDT/1984 dated January 30, 1986, Indonesia's positive law also provides several alternatives that can be taken by creditors in taking repayment of receivables that are experiencing congestion in their repayments, namely:

a. File a civil suit;

b. Submit a request for execution on the basis of Article $224 \mathrm{HIR}$;

c. Submit to the Committee for State Receivable Affairs (PUPN);

d. Submit an application for auction on the basis of Article 1178 paragraph (2) BW;

e. Conducting sales under the hands on the basis of Article 17 paragraph (1) of Act No. 16 of 1985 concerning Flats (UURS).

When studied in theory of legal protection, what is meant by legal protection itself is the effort or form of service provided by law to legal subjects and things that are protected objects. Basically, the shift in the position of creditors from

\footnotetext{
${ }^{18}$ Titik Triwulan Tutik, 2008, Hukum Perdata dalam Sistim Hukum Nasional, Kencana Prenada Media Group, Surabaya, p. 358

${ }^{19}$ Results of an interview with Mr. Norman Subowo, Head of the Land Office of Palembang City on Monday, July 8, 2021. At 10.00 WIB
} 
preferred creditors to concurrent creditors still provides legal protection, namely legal protection in general in Article 1131 of the Civil Code where all debtor assets are guaranteed to pay off debts in the event of default. However, in this context the form of legal protection provided has also experienced a degradation or juridical weakening. Because if you look at the risk that will be borne by the bank, it is not comparable to losing the privilege of treating the object of Mortgage. $^{20}$

Preventive legal protection itself is legal protection that is preventive in nature. This means that after the Court's decision that cancels the certificate of Ownership that is burdened with the Mortgage, in principle the credit agreement is still valid, because the Mortgage itself is an additional agreement. So it cannot be said that the credit is directly problematic, but the risk of loss of this Mortgage will have an impact on paying off debts in the event of non-performing loans. Therefore, a prevention is needed as an effort to provide legal protection for creditors, namely based on Article 1338 Paragraph (3) of the Civil Code, namely the principle of good faith for mediation between the two parties regarding the collateral object,

Another form of legal protection that can be used is to use repressive legal protection, namely the final protection in the form of sanctions such as fines, imprisonment, and additional penalties given if a dispute has occurred or a violation has been committed. Which aims to resolve disputes between creditors and debtors in the event of non-performing loans in the case of a Mortgage agreement caused by the abolition of the land rights of the Ownership Rights charged with the Mortgage Rights. Where the debtor must be obliged to pay off the remaining debt to the creditor, so that the creditor has the right to execute the object of the debtor's Mortgage to take advantage and pay off the debtor's debt.

About it Moh. Isnaeni is of the opinion that the aggrieved party can file a lawsuit to the court along with the application for the placement of the confiscation of collateral on the property of the party who defaults. Based on the lawsuit, if it is decided that the party in default is proven guilty, it is obligatory to fulfill the contents of the judge's decision that has been incracht, namely to pay compensation. ${ }^{21}$

Based on this article, there are two ways to determine the starting point for calculating compensation, namely as follows:

\footnotetext{
${ }^{20}$ Salim HS and Erlies Septiana Nurhani, Op. cit, p. 262.

${ }^{21}$ Moch. Isnaeni, Lembaga Jaminan Kebendaan Dalam Burgerlijk Wetboek : Gadai \& Hipotek, Revka Petra Media, 2016, p. 5
} 
a. If the agreement does not specify a period of time, the payment of compensation starts from the time the party has been declared negligent, but continues to neglect it.

b. If the agreement has specified a certain period of time, the payment of compensation begins to be calculated from the expiration of the specified period.

In this repressive legal protection, it means that this legal protection will be used in the event of bad credit and the collateral itself has been written off. Which is where creditors can carry out this repressive legal protection and can be achieved through mediation (non-litigation) which may be the National Land Agency can become a facilitator or litigation (court institution). ${ }^{22}$

So according to the author, if studied in theory of legal protection, it can be concluded that banks have protection against repayment of their receivables. Even though there is a claim by another party against the object of collateral that is used as a Mortgage, the bank is still entitled to the settlement of its receivables. Efforts that must be made by banks are to carry out litigation efforts in civil cases in accordance with Supreme Court Decision Number 3201 K/Pdt/1984. Banks outside of these efforts can also seek non-litigation solutions with debtors to pay off their debts.

\section{Closing}

As a result of the abolition of the object of Mortgage, namely the certificate of land rights as a material agreement, it does not mean abolishing one's obligations as a debtor, but rather has legal consequences, namely the first legal status due to the cancellation of the certificate of ownership of land that is being burdened with Mortgage Rights, namely the change in the position of the creditor, which initially is domiciled as a preferred creditor who has material rights, then is domiciled as a concurrent creditor who has individual rights. What can be concluded in a general guarantee, all creditors have the same position against other creditors, no creditor is prioritized or privileged over other creditors. Forms of legal protection that can be taken in this case are preventive legal protection and repressive legal protection. Preventive legal protection is legal protection that is preventive in nature, that is, it can be through an agreement by including a clause regarding the replacement of the dependent object with other objects owned by the debtor in the event of the elimination of the right to the dependent object that is burdened with the mortgage.

\footnotetext{
${ }^{22}$ Results of an interview with Mr. Norman Subowo, Head of the Land Office of Palembang City on Monday, July 8, 2021. At 10.00 WIB
} 
Meanwhile, repressive legal protection can be achieved through mediation (nonlitigation) which may be the National Land Agency can be a facilitator or litigation obtained by creditors by filing a lawsuit to the court along with the application for the placement of collateral for the property of the party who defaults.

\section{References}

Journals:

[1] A Chuasanga, Ong Argo Victoria. (2019). Legal Principles Under Criminal Law in Indonesia \& Thailand, Jurnal Daulat Hukum, Vol 2, No 1 (2019) http://jurnal.unissula.ac.id/index.php/RH/article/view/4218

[2] Deen, Thaufiq., Ong Argo Victoria \& Sumain. (2018). Public Notary Services In Malaysia. JURNAL AKTA: Vol. 5, No. 4, 1017-1026. Retrieved from http://jurnal.unissula.ac.id/index.php/akta/article/view/4135

Books:

[1] Adrian Sutedi. 2010, Hukum Hak Tanggungan, Sinar Grafika, Jakarta

[2] Amiruddin \& Zainal Asikin, 2014, Pengantar metode Penilitian Hukum, Raja Grafindo Persada, Jakarta.

[3] Hilman Hadikusuma, 1995, Metode Pembuatan Kertas Kerja atau Skripsi Ilmu Hukum, Mandar Maju, Bandung

[4] Hatta Isnaini Wahyu Utomo, 2017, Hukum Jaminan, Bahan Ajar, Surabaya: Fakultas Hukum Universitas Yos Sudarso

[5] J. Satrio, 1998, Hukum Jaminan, Hak Kebendaan, Hak Tanggungan, Citra Aditya Bhakti, Bandung

[6] Man S. Sastrawidjaja, 2014, Hukum Kepailitan \& Penundaan Kewajiban Pembayaran Utang, Bandung: Alumni

[7] Moch. Isnaeni, 2016, Lembaga Jaminan Kebendaan Dalam Burgerlijk Wetboek : Gadai \& Hipotek, Revka Petra Media.

[8] Salim, HS. 2007, Perkembangan Hukum Jaminan di Indonesia, Raja Grafindo Persada, Jakarta

[9] Sutan Remy Sjahdeini, 2010, Hukum Kepailitian, Jakarta: Grafiti,

[10] Suharismi Arikunto, 2013 , Dasar-Dasar Evaluasi Pendidikan, Bumi Aksara, Jakarta

[11] Trisadini Prasastinah Usanti, \& Leonora Bakarbessy, 2016, Buku Referensi Hukum Perbankan Hukum Jaminan, Revka Petra Media.

[12] Titik Triwulan Tutik, 2008, Hukum Perdata dalam Sistim Hukum Nasional, Kencana Prenada Media Group, Surabaya

[13] Amiruddin \& Zainal Asikin, 2014, Pengantar metode Penilitian Hukum, Raja Grafindo Persada, Jakarta. 